Song

of the

dynamo

(0 Canto do Dínamo)

SONG OI:TIIE DYNAMO

The Fatber of Lightning -

How Pouter came to São Paulo

Ilow do I know what Order brings

Traduclo de RONALD DE CARVALHO e apresentagdo de ULPIANO BEZEARA DE' MENESES

o Captral descobre a mãe GENTIL - Os séculos XIX-XX. sem exagero, podem ser tomados como a nova cra dos descobrimen. tos. aquela produzida pelo capital na sua colonização de espaços virgens e acolhedores, conduzindo à divisâo internacional do trabalho e a formaçăo da cconomia-mundo de que falam os especialistas.

O poeta ingles Rudyard Kipling (1865-1936), porta-voz da missão coilonizadora do Império Britânico, $\mathrm{cm}$ visita ao Brasil, em 1928. impressionou-se com o complexo hidrelétrico da Light, na Serra do Mar (empresa canadense que nos introduziu ds maravilhas da - fada eletricidade-), alimentando uma Sáo Paulo em ebuliçáo e cheia de esperanças.

Esta visato the inspirou o poema "O Canto do Dínamo", cujo original se acha depositado no Arquuivo Histórico da Eletropaulo, assim como a traducto, feita pelo pocta Ronald de Carvalho.

$$
\text { Me into being? }
$$

I only know, if you do certains things,

I must become your llearing and your Seeing

Also your Strength, to make great wheels I go round And save your sons from toil, while I am bound!

What do I care bou' you dispose The Powers that move me?

I only know that I am one utitb those

True Powers wbich rend the firmament above me,

And, barrying earth, would save me at last But that your could foresight bolds me fast! 


\title{
O CANTO DO DÍNAMO
}

\author{
O Pai dos Relâmpagos - \\ Como o Poder veio a São Paulo
}

Como poderia saber que Providência me deu o ser?

Sei apenas que, a um aceno vosso,

devo tornar-me vosso ouvido e vossos olhos;

E vossa Força, também, para fazer girar grandes rodas

E libertar do jugo vossos filhos, enquanto permaneço agrilhoado!

Que importa conhecerdes os poderes que me movem?

Sei apenas que estou conjugado àqueles verdadeiros poderes, que rompem os espaços alterosos,

E, violentando a Terra, poderiam salvar-me, um dia

Se não fosse o espectro covarde que me retém para sempre encadeado*. 